\title{
Cover crops as modifying agents of microbiological soil attribute
}

Catia Aparecida Simon ${ }^{1 *}$, Sebastião Ferreira de Lima², Meire Silvestrini Cordeiro ${ }^{2}$, Vinícius Andrade Secco ${ }^{2}$, Guilherme Nacata ${ }^{3}$, Antonio Marcos Miranda Silva ${ }^{1}$, Camila da Conceição Simon ${ }^{4}$, Marivaine da Silva Brasil ${ }^{5}$

\author{
${ }^{1}$ Department of Soil Science, Luiz de Queiroz College of Agriculture, University of São Paulo, Piracicaba - SP, Brazil \\ ${ }^{2}$ Federal University of Mato Grosso do Sul, Chapadão do Sul campus, Chapadão do Sul - MS, Brazil \\ ${ }^{3}$ Department of Plant Production, Luiz de Queiroz College of Agriculture, University of São Paulo, Piracicaba - SP, \\ Brazil \\ ${ }^{4}$ Technical in Agriculture, Castelo - ES, Brazil \\ ${ }^{5}$ Federal University of Mato Grosso do Sul, Corumbá campus, Corumbá - MS, Brazil
}

\section{*Corresponding author: catiasimon@usp.br}

Abstract

\begin{abstract}
Carbon sources are exuded and deposited by different soil cover plants. They promote growth, diversity and enhancement of soil microbial community functionality, due to organic matter degradation by participating in major biochemical cycles and the availability of inorganic nutrients to plants. In this way, it is necessary to evaluate the microbiological attributes of the soil after cover cropping, which allows for surveying and monitoring the soil quality, thereby enabling rapid responses in relation to managing changes in the soil. Thus, the objective of this study was to evaluate soil microbiological attributes and soybean grain yield under the influence of different cover crops. The experiment was installed in the year 2015. The treatments were constituted by the following vegetation coverages: sorghum, millet, Urochloa ruziziensis, forage turnip, Urochloa brizantha, crambe and fallow area, with cover crops sown in succession to the soybean crop for three years prior to the date of installation of the experiment .The evaluated parameters were soil microbial biomass carbon, soil basal respiration, metabolic quotient, enzymatic activity of acid phosphatase and soil $\beta$-glucosidase, plant phytomass produced by the different cover crops and soybean yield in each area. The use of cover crops promotes higher soybean yield. The microbial activity and its efficiency were modulated according to the type of cover crop used. Soil under sorghum mulch provided lower microbial efficiency. The $U$. ruziziensis plant residues remain for less time on the soil. The results show that $U$. brizantha may be the most suitable for its use as a soil cover plant, providing improvements in its attributes.
\end{abstract}

Keywords: Acid phosphatase; $\beta$-glucosidase; plant diversity; Glycine max L.; Urochloa brizantha.

\section{Introduction}

Soil microbial ecology is difficult to understand because of the high degree of biological diversity and spatial heterogeneity of soils (Raynaud and Nunan, 2014). However, it is known that the functioning of the soil microbial community is important for understanding the processes that occur in the ecosystem (Chavez et al., 2011), in which the complex interactions within a specific ecological niche and the understanding of interactions between microorganisms are important in order to explore the complexity of functional processes (Faust and Raes, 2012). Soil organic matter decomposition is a process mediated by enzymes that can be excreted (extracellular) by living cells or released by disintegrating cells releasing such enzymes. These enzymes are mainly produced by soil microorganisms (bacteria, archaea and fungi) and by some plants, which are the main catalysts for depolymerizing and mineralizing organic compounds in the soil (Gessner et al., 2010; Stott et al., 2010). Extracellular enzymes determine rates of decomposition, immobilization and mineralization of organic matter, allowing for flow of nutrients, species survival and soil functioning (Zhang et al., 2015).

Analysing soil enzymatic activity, as well as quantifying microbial biomass carbon $(\mathrm{MBC})$, soil basal respiration (C$\mathrm{CO}_{2}$ ) and metabolic quotient $\left(q \mathrm{CO}_{2}\right)$, can be used to indicate soil potential in relation to biochemical reactions, and also provide important data for understanding the functioning of the soil system, in addition to providing information for management practices (Adamczyk et al., 2014).

In order to increase soil microbial diversity and microbial activity (Bhavya et al., 2018), soil organic matter supply from cover crop cultivation may stimulate the soil microbial community. The microbial community of the soil is responsible for indicating more quickly about changes in the soil system due to the adopted management (Medeiros et al., 2017). In this way, soil management practices such as conventional planting system, no-tillage system, 
monoculture cultivation, succession and crop rotation, and the use of different plant species can modulate and directly influence soil biology. more efficient and rapid biological indicators of soil change when compared to chemical and physical soil analyzes (Ferreira et al. 2018).

It should be emphasized that biological attributes are important indicators of soil quality because they are sensitive to soil management, as described by Lourente et al. (2011), where they confirmed that microbiological attributes are efficient indicators of changes in physical attributes as a function of soil management and use. The enzymatic activity of the soil varies according to its use, in which the activity of dehydrogenases and proteases, together with the levels of organic carbon and total nitrogen of the soil are higher in soils with crop rotation, when compared to soils cultivated with monocultures (Koper and Piotrowska, 1999; Błońsk et al., 2017).

Thus, studying microbial biomass carbon changes and their activity in the soil as a consequence of implementing different cover crops is of great relevance, as they can provide subsidies for land use decision-making and the choice of vegetal composition to compose crop rotation, thereby contributing to better productivity of the commercial crop, in addition to enabling better quality and fertility of the soil.

The objective of this work was to evaluate the microbial biomass carbon and the microbiol activity (metabolic quotient, enzymatic activity of acid phosphatase, $\beta$ glucosidase and arylsulfatase) in soil samples of Cerrado under influence of different cover crops on soybean yield.

\section{Results}

\section{Soil chemical characteristics}

Interpreting the soil chemical analyzes was performed based on the recommendations of Souza and Lobato (2004) for correcting and fertilizing soil in the State of Mato Grosso do Sul (Table 1). All P contents found in the growing area were classified as good. The highest $\mathrm{P}$ content was for the $U$. brizantha area $\left(25.1 \mathrm{P} / \mathrm{dm}^{3}\right.$ soil), followed by fallow areas (24.4 $\mathrm{P} / \mathrm{dm}^{3}$ soil) and crambe $\left(21.2 \mathrm{P} / \mathrm{dm}^{3}\right.$ soil), and the lowest content found for the area planted with millet (12.4 $\mathrm{P} / \mathrm{dm}^{3}$ soil). The $\mathrm{K}$ content was considered average (ranging from $51-80 \mathrm{mg} \mathrm{dm}^{-3}$ ) for all cultivated soils, except for the soil cultivated with $U$. ruzizienses which presented the highest content, and was considered good $\left(>80 \mathrm{mg} \mathrm{dm}^{-3}\right)$. In the literature, the $\mathrm{Zn}$ (zinc) content for the Cerrado region can be classified as low $\left(<1.0 \mathrm{mg} \mathrm{dm}^{-3}\right.$ ), medium (1.1 to 1.6 $\left.\mathrm{mg} \mathrm{dm}^{-3}\right)$ and good $\left(<1.6 \mathrm{mg} \mathrm{dm}^{-3}\right)$. Very high levels were found in the study areas, in which the values ranged from 5.5 to $15.5 \mathrm{mg} / \mathrm{dm}^{-3}$, especially the area cultivated with sorghum, which presented very high zinc content (15.5 $\mathrm{mg} / \mathrm{dm}^{-3}$ ). The $\mathrm{Mg}$ contents were high (> $10 \mathrm{mmolc} \mathrm{dm}^{-3}$ ) (Raij et al., 1996), while the Ca contents were in the average range $\left(2.1\right.$ to $\left.4.0 \mathrm{cmolc} / \mathrm{dm}^{-3}\right)$, except for the area cultivated with millet $\left(>4.0 \mathrm{cmolc} / \mathrm{dm}^{-3}\right)$, considered as high.

\section{Microbial biomass carbon, basal respiration and soil metabolic quotient}

Significant differences were identified in the variance analysis for the studied variables, except for the soil microbial quotient $\left(\mathrm{qCO}_{2}\right)$ (Table 2). Soil microbial biomass (MBC) was higher in the areas of millet, $U$. ruzizienses, forage turnip, U. brizantha, and crambe (489.32, 439.69, $427.16,413.72$ and $462.12 \mathrm{mg} \mathrm{kg}^{-1}$ of $\mathrm{C}_{\text {mic }}$ in the soil, respectively) when compared to the sorghum area (Figure 3). For soil basal respiration $\left(\mathrm{C}-\mathrm{CO}_{2}\right)$, the results in descending order according to the evaluated treatments were: millet $=$ crambe $>$ forage turnip $=U$. brizantha $=U$. ruzizienses $>$ fallow $=$ sorghum (Figure 4 ).

\section{Soil enzymatic activity}

The values of acid phosphatase oscillated between 581.56 and $451.63 \mu \mathrm{g}$ p-nitrophenol kg soil ${ }^{-1} \mathrm{~h}^{-1}$, with the highest values being obtained with the soil under forage turnip, $U$. brizantha and $U$. ruziziensis mulch, being similar to each other (Table 3). The highest values found for the $\beta$ glucosidase enzyme obtained in descending order were for $U$. Brizantha $=$ millet $=$ crambe $>$ fallow $=$ forage turnip $=U$. Ruzizienses > sorghum, with values ranging from 94.58 to 143.25 $\mu \mathrm{g} \mathrm{p-nitrophenol} \mathrm{kg} \mathrm{soil}{ }^{-1} \mathrm{~h}^{-1}$ (Table 3).

\section{Vegetable phytomass and productivity}

Sorghum cultivation presented higher phytomass value $\left(7,304.33 \mathrm{~kg} \mathrm{ha}^{-1}\right)$, differing from other treatments, while $U$. brizantha presented lower values for phytomass $(1,693.66$ $\left.\mathrm{kg} \mathrm{ha}^{-1}\right)$. The least amount of phytomass for $U$. brizantha in the area was probably due to a failure in seed germination, thus reducing the vegetal material contributed under the soil (Figure 5).

The areas with highest $(p \leq 0.05)$ soybean yield for the 2015/2016 crop were found under soil cultivated with $U$. brizantha, $U$. ruzizienses and millet $(4,023.51,3,850.58$ and $3,947.38 \mathrm{~kg} \mathrm{ha}^{-1}$, respectively), not differing from each other. The area with the lowest soybean yield occurred under the fallow soil $\left(3,014.00 \mathrm{~kg} \mathrm{ha}^{-1}\right)$ and under the area cultivated with crambe $\left(3,162.51 \mathrm{~kg} \mathrm{ha}^{-1}\right)$, which did not differ between them.

\section{Discussion}

The MBC value in the fallow soil before soybean cultivation resembled soils under all cover crops, except for sorghum, which presented a lower value $\left(320.70 \mathrm{mg} \mathrm{kg}^{-1}\right.$ of $C_{\text {mic }}$ in the soil) (Fig 3). The high MBC values found in cultivated soils can be related to the type of soil management, in which the no-tillage system does not cause the soil to rotate and promotes the organic $\mathrm{C}$ supply to the soil microbial biomass (Balota et al., 2003), and although the direct seeding system is the same for the sorghum cultivated area, the zinc content found in this area is high, probably negatively influencing MBC.

For the soil $\mathrm{C}-\mathrm{CO}_{2}$, the areas cultivated with crambe and millet obtained higher microbial $\mathrm{C}_{-} \mathrm{CO}_{2}$ values (Fig 4). According to Reis Júnior and Mendes (2007), the soil $\mathrm{C}-\mathrm{CO}_{2}$ can be influenced by the moisture, temperature and availability of nutrients in the soil, and (according to these authors), interpreting soil $\mathrm{C}-\mathrm{CO}_{2}$ can follow two lines; one in which the high soil basal respiration rate can be considered positive, considering that the decomposing organic residues will provide nutrients to the plants; and the second aspect concerns a disturbance caused by high productivity in the 
Table 1. Soil chemical composition and composition of the experimental area, Chapadão do Sul, MS.

\begin{tabular}{|c|c|c|c|c|c|c|c|c|c|c|c|c|c|}
\hline \multirow{2}{*}{ Area } & Clay & Silt & Sand & \multirow{2}{*}{$\begin{array}{l}\mathrm{OM} \\
\%\end{array}$} & \multirow{2}{*}{$\begin{array}{l}\mathrm{pH} \\
\left(\mathrm{CaCl}_{2}\right)\end{array}$} & \multirow{2}{*}{$\begin{array}{l}\mathrm{V} \\
\%\end{array}$} & \multirow{2}{*}{\multicolumn{3}{|c|}{$\begin{array}{l}\mathrm{P} \\
\mathrm{M}\end{array}$}} & \multirow{2}{*}{\multicolumn{4}{|c|}{$\mathrm{cmol}_{\mathrm{c}} / \mathrm{dm}^{3}$}} \\
\hline & ------ & $---\%$ & & & & & & & & & & & \\
\hline Sorghum & 41.0 & 19.0 & 40.0 & 2.9 & 5.1 & 50.7 & 14.8 & 53.0 & 15.5 & 2.3 & 1.16 & 3.5 & 7.1 \\
\hline Millet & 41.0 & 17.0 & 42.0 & 3.2 & 6.2 & 79.6 & 12.4 & 78.0 & 5.5 & 4.8 & 1.65 & 1.7 & 8.3 \\
\hline U. ruzizienses & 38.0 & 11.0 & 51.0 & 2.7 & 5.6 & 72.7 & 20.6 & 86.0 & 8.1 & 3.2 & 1.63 & 1.9 & 6.9 \\
\hline Forage turnip & 39.0 & 19.0 & 42.0 & 2.3 & 5.4 & 60.3 & 17.3 & 53.0 & 6.7 & 2.9 & 1.21 & 2.8 & 7.0 \\
\hline U. brizantha & 38.0 & 20.0 & 42.0 & 2.9 & 5.4 & 69.0 & 25.1 & 71.0 & 7.4 & 3.4 & 1.54 & 2.3 & 7.4 \\
\hline Crambe & 42.0 & 20.0 & 38.0 & 3.0 & 5.8 & 67.4 & 21.2 & 70.0 & 5.7 & 3.1 & 1.47 & 2.3 & 7.0 \\
\hline Fallow & 44.0 & 18.0 & 38.0 & 2.6 & 5.8 & 74.0 & 24.4 & 65.0 & 7.2 & 3.9 & 1.90 & 2.1 & 8.1 \\
\hline
\end{tabular}

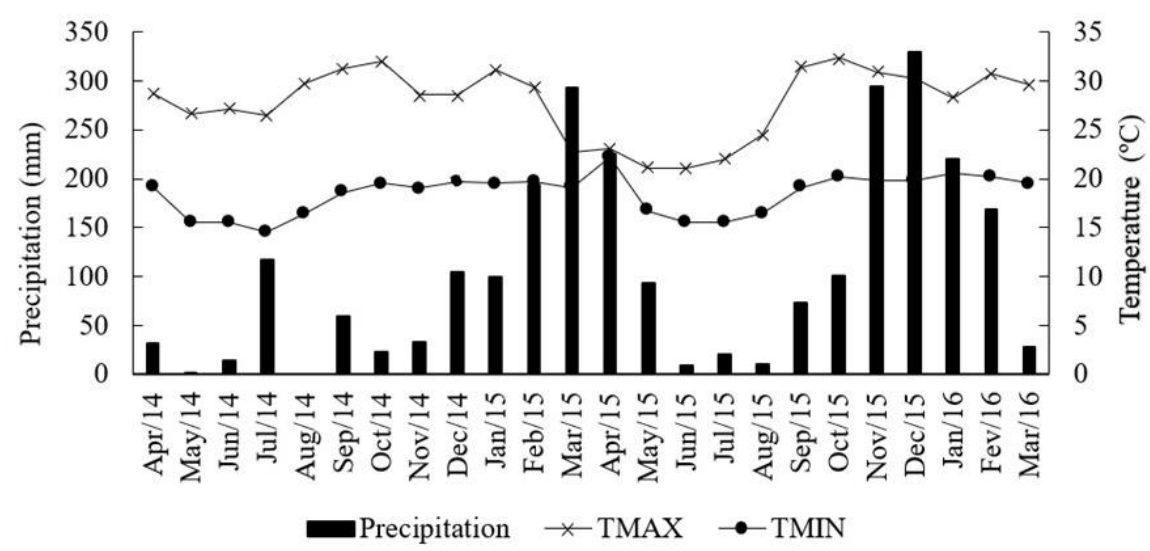

Fig 1. Precipitation, maximum monthly temperature (TMAX) and minimum monthly temperature (TMIN) observed during the experiment, according to data provided by the National Institute of Meteorology, Chapadão do Sul, MS.

Table 2. ANOVA chart for microbial biomass carbon variables $(\mathrm{MBC})$, soil basal respiration $\left(\mathrm{C}-\mathrm{CO}_{2}\right)$, metabolic quotient $\left(q C \mathrm{CO}_{2}\right)$, acid phosphatase (EAP), $\beta$-glucosidase (EBG), phytomass (PTM) and soybean yield (Y) in a soybean plantation under succession of six different cover crops and a fallow area.

\begin{tabular}{|c|c|c|c|c|c|c|c|c|}
\hline \multirow{2}{*}{ VS } & \multirow{2}{*}{ DF } & \multicolumn{7}{|l|}{$\mathrm{QM}$} \\
\hline & & $\mathrm{MBC}$ & $\mathrm{C}-\mathrm{CO}_{2}$ & $q \mathrm{CO}_{2}$ & EAP & EBG & PTM & $\mathrm{Y}$ \\
\hline $\mathrm{CO}$ & 5 & $10580.69 * *$ & $661.32 * *$ & $0.43^{\text {ns }}$ & 7853.19** & $899.31^{* *}$ & $16890007.06 * *$ & $451821.19 * *$ \\
\hline $\mathrm{BL}$ & 2 & 5545.87 & 55.40 & 0.58 & 33.32 & 126.33 & 6217.00 & 474.65 \\
\hline $\mathrm{RE}$ & 10 & 1714.09 & 56.48 & 0.19 & 344.51 & 31.74 & 6247.72 & 10398.06 \\
\hline CV (\%) & & 9.50 & 5.32 & 12.70 & 3.55 & 4.33 & 2.60 & 2.84 \\
\hline
\end{tabular}

**Significant at $1 \%$ probability; VS=variation source; $\mathrm{DF}=$ degrees of freedom; $\mathrm{CO}=$ covers; $\mathrm{BL}=$ blocks; $\mathrm{RE}=$ residue; $\mathrm{CV}=$ coefficient of variation; $\mathrm{ns}=$ not significant

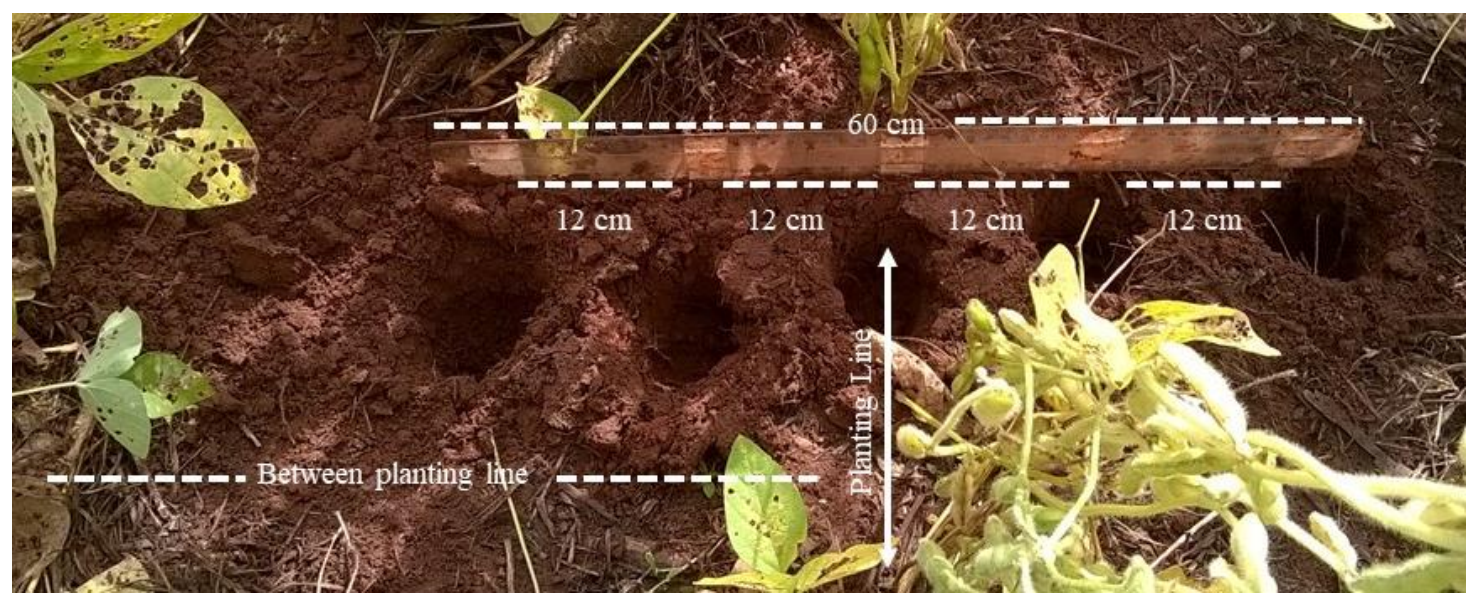

Fig 2. Procedure for collecting a soil sample. Each composite sample consists of collecting five sub-samples of soil, equidistant by 12 $\mathrm{cm}$ with a hole in the planting line and two holes in the crop line. 
Table 3. Effect of different cover crops on the microbial activity of acid phosphatase (EAP) and $\beta$-glucosidase (EBG) of a dystrophic Red Latosol soil under soybean planting in succession of six different cover crops and one fallow area.

\begin{tabular}{llc}
\hline Cover crops & $\begin{array}{l}\text { EAP } \\
\left(\mu \mathrm{g} \mathrm{p} \text { - nitrophenol kg soil }{ }^{-1} \mathrm{~h}^{-1}\right)\end{array}$ \\
\hline SOR & $516.05 \mathrm{~b}$ & $94.58 \mathrm{c}$ \\
MIL & $512.20 \mathrm{~b}$ & $143.18 \mathrm{a}$ \\
URU & $559.05 \mathrm{a}$ & $124.69 \mathrm{~b}$ \\
FT & $581.56 \mathrm{a}$ & $131.21 \mathrm{~b}$ \\
URB & $572.86 \mathrm{a}$ & $143.25 \mathrm{a}$ \\
CRA & $466.14 \mathrm{c}$ & $142.78 \mathrm{a}$ \\
FAL & $451.63 \mathrm{c}$ & $131.55 \mathrm{~b}$ \\
\hline
\end{tabular}

SOR: Sorghum; MIL: Millet; URU: U. ruzizienses; FT: Forrage turnip; UBR: U. brizantha; CRA: Crambe; FAL: Fallow area. Averages followed by the same letter in the column do not differ from each other by the Scott Knott test at $1 \%$ probability.

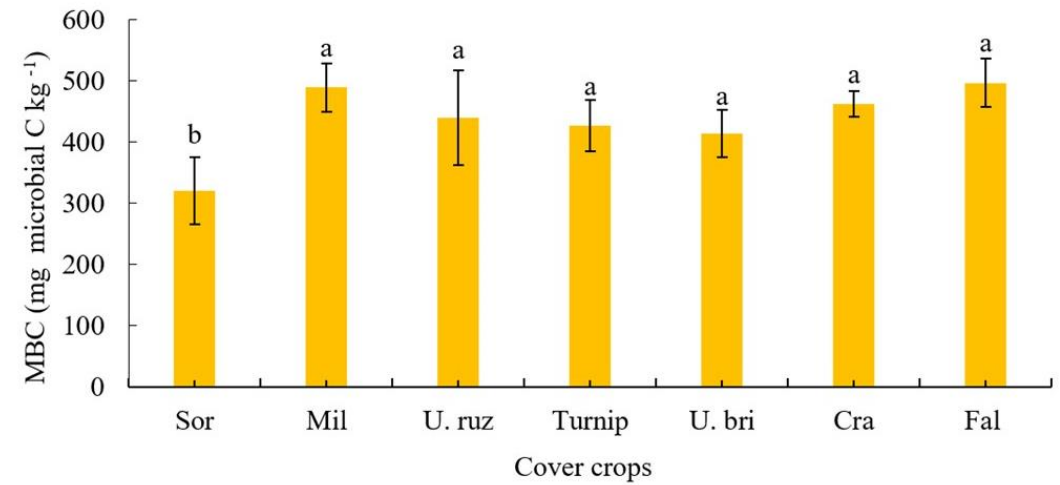

Fig 3. Effect of different cover crops on microbial biomass carbon (MBC) of a dystrophic Red Latosol soil. Sor=Sorghum; Mil=Millet; $U$. ruz=U. ruzizienses; Turnip=Forrage turnip; U. bri=U. brizantha; $\mathrm{Cra}=\mathrm{Crambe}$; Fal=Fallow. The bars represent the standard deviation of three replicates. Different letters indicate significance of $p<0.05$ between treatments composed of different cover crops on soil cultivated in succession to soybean.

Table 4. Pearson correlation coefficient $(p<0.05)$ obtained for microbial biomass carbon $(\mathrm{MBC})$, soil basal respiration $\left(C-\mathrm{CO}_{2}\right)$, metabolic quotient $\left(\mathrm{qCO}_{2}\right)$, acid phosphatase (EAP), $\beta$-glucosidase (EBG), plant phytomass (PTM), and soybean yield (Y) in soybean plantation under succession of six different cover crops and one fallow area.

\begin{tabular}{llllllll}
\hline & $\mathrm{C}^{-} \mathrm{CO}_{2}$ & $\mathrm{MBC}$ & $\mathrm{qCO}_{2}$ & $\mathrm{EAP}$ & $\mathrm{EBG}$ & $\mathrm{PTM}$ & $\mathrm{Y}$ \\
\hline $\mathrm{C}-\mathrm{CO}_{2}$ & 1.0 & & & & & & \\
$\mathrm{MBC}$ & 0.62 & 1.0 & & & & & \\
$\mathrm{qCO}_{2}$ & -0.03 & $-0.79^{*}$ & 1.0 & & & & \\
$\mathrm{EAP}$ & -0.01 & -0.39 & 0.43 & 1.0 & & & \\
$\mathrm{EBG}$ & $0.78^{*}$ & $0.79^{*}$ & -0.46 & -0.03 & 1.0 & & \\
$\mathrm{PTM}$ & -0.05 & -0.67 & $0.87^{*}$ & 0.12 & -0.61 & 1.0 & \\
$\mathrm{Y}$ & 0.45 & 0.07 & -0.6 & 0.57 & 0.12 & -0.1 & 1.0 \\
\hline \multicolumn{7}{c}{$*$ Significant at 5\% probability. } \\
\hline \multicolumn{7}{c}{}
\end{tabular}

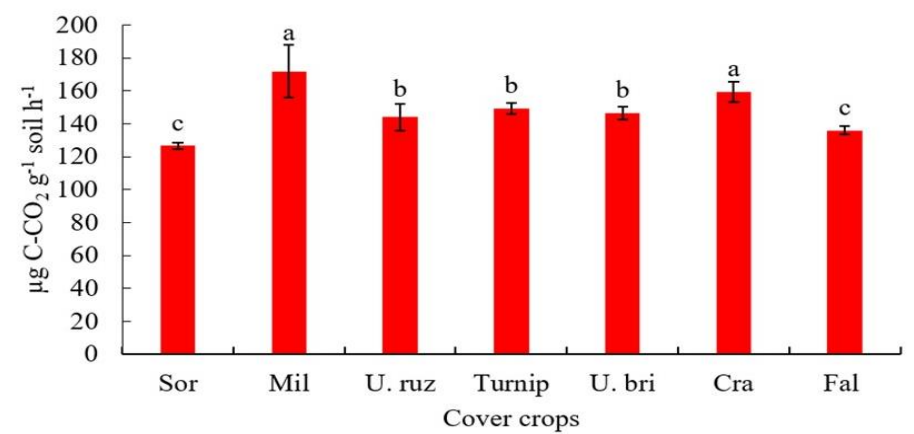

Fig 4. Effect of different cover crops on basal soil respiration $\left(\mathrm{C}_{-}-\mathrm{CO}_{2}\right)$ of a dystrophic Red Latosol soil. Sor=Sorghum; Mil=Millet; U.

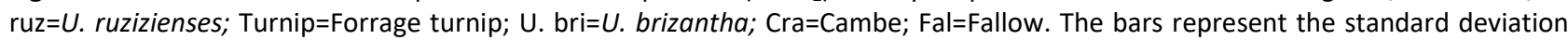
of three replicates. Different letters indicate significance of $p<0.05$ between the treatments composed by different cover crops on soil grown in succession to soybean. 


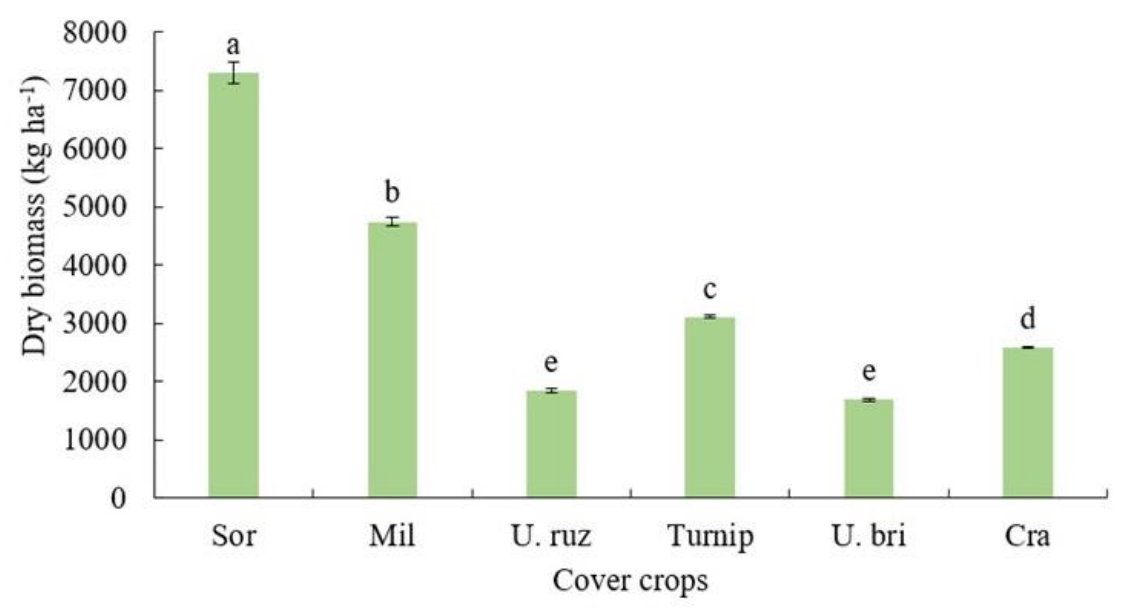

Fig 5. Dry biomass produced by different vegetation cover plants on soil cultivated in soybean succession. Sor=Sorghum; Mil=Millet; U. ruz $=U$. ruzizienses; Turnip=Forrage turnip; U. bri $=U$. brizantha; Cra=Crambe; Fal=Fallow. The bars represent the standard deviation of three replicates. Different letters indicate significance of $p<0.05$ between treatments.

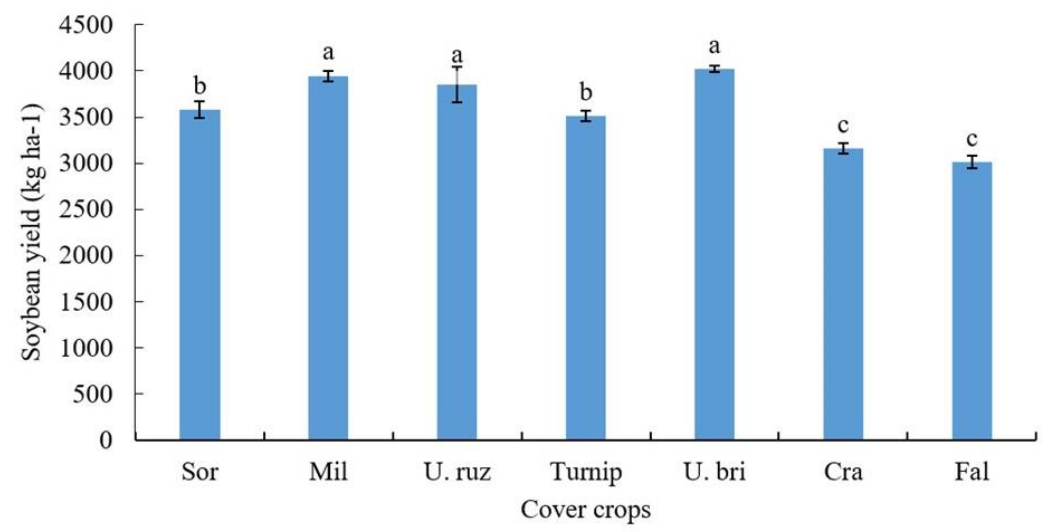

Fig 6. Soybean yield cultivated under soil subjected to succession of different cover crops. Sor=Sorghum; Mil=Millet; $U$. ruz=U. ruzizienses; Turnip=Forage turnip; U. bri=U. brizantha; Cra=Crambe; Fal=Fallow. The bars represent the standard deviation of three replicates. Different letters indicate significance of $p \leq 0.05$ between treatments.

microbial system and nutrient losses due to decomposition of stable organic matter, thereby increasing $\mathrm{C}-\mathrm{CO}_{2}$. Thus, it can be inferred that management with grasses in a no-tillage system enabled lower $\mathrm{CO}_{2}$ flow due to lower organic matter mineralization in the soil.

There was no statistical difference for the metabolic quotient $\left(\mathrm{qCO}_{2}\right)$ parameter; however, the results are similar to the results obtained by Guimarães et al. (2017), in which high values found (values between 2.74 and 4.03) may indicate that the soil microbial community must be expending energy for its maintenance, or probably the soil microbial community is in an early development stage and has a higher proportion of active microorganisms than inactive ones (Gomide et al., 2011; Roscoe et al., 2006).

According to Taiz et al. (2017), P is an essential element for plant development due to its participation in vital functions to plant development. This element can be found in organic (Po) and inorganic form (mainly in the form of $\mathrm{H}_{2} \mathrm{PO}_{4}{ }^{-}$) in the soil, with the latter being assimilated by plants and microorganisms therein. Thus, soil microorganisms play a key role in $\mathrm{P}$ cycling, participating in the processes of mineralization and immobilization and availability of this element. In addition, the microorganisms are the main solubilizers of $P$ in the soil, making it possible to replace the available P (Cardoso and Andreote, 2016). However, for Massenssini et al. (2015), P solubilization depends on the microbial community interaction with the plant species, in which the enzymatic activity can be modulated according to the root exudate composition. About 5 to $25 \%$ of the total $C$ fixed by photosynthesis can be transferred to the rhizosphere via root exudates, and thus induce and stimulate microbial growth, and in most cases select the specific microbial communities (Haichar et al., 2014). Plants are able to modulate the rhizosphere environment according to their physiological needs, therefore another determining factor for acid phosphatase activity is the relationship of soil fertility to plant needs. Although $P$ levels found in the experimental areas are classified as good (Souza and Lobato, 2004), it can be verified that the lowest $P$ levels found in the soil cultivated with sorghum $\left(14.8 \mathrm{P} / \mathrm{dm}^{3}\right.$ soil) and millet $\left(12.4 \mathrm{P} / \mathrm{dm}^{3}\right.$ soil) may be related to the mean values found for acid phosphatase activity (Table 3 ). The highest acid phosphatase activity (Table 3 ) was observed for U. brizantha and $U$. ruzizienses cover crops, although there was no higher phytomass production (Figure 5) when compared to the other cover crops. It can be said that the roots of these plants influenced the acid phosphatase activity due to their morphology (Mendes et al., 2012). The high acid phosphatase value for the soil under forage turnip (581.56 
$\mu \mathrm{g}$-nitrophenol $\mathrm{kg} \mathrm{soil}^{-1} \mathrm{~h}^{-1}$ ) is similar to the results described by Kunze et al. (2011), in which the authors obtained higher values of this enzyme in soil cultivated with forage turnip when compared to the fallow area soil through evaluating the effect of mycorrhizal and nonmicrocytic cover plants on the acid phosphatase activity at different periods of cultivation.

B-glycosidase is also an enzyme of great importance within biogeochemical cycles, participating from a finalizing group of cellobiose hydrolysis to glucose, promoting the release of nutrients from organic matter, and its activity is related to the amount of mineralizable C (Lisboa et al., 2012; Tabatabai, 1994). The lowest value of $\beta$-glucosidase enzymatic activity was found in soil cultivated with sorghum (94.58 $\mathrm{\mu g}$ p-nitrophenol kg soil ${ }^{-1} \mathrm{~h}^{-1}$ ) (Table 3), which when combined with its carbon/nitrogen ratio (34/1), and its phytomass production (Figure 5), may indicate slower decomposition of its mulch due to the greater accumulation of carbon in the soil from the low microbial community's excretory activity of the $\beta$-glucosidase enzyme (Makoi and Ndakidemi, 2008), moreover, its activity is controlled by the quantity and quality of litter. The results of this study are similar to those of Torres et al. (2008), when they evaluated the influence of different cover crops (millet, U. brizantha, forage sorghum, pigeon pea, Crotalaria juncea and black oats) on Dystrophic Red Latosol soil. In this work, it was observed that the sorghum $\mathrm{C} / \mathrm{N}$ ratio (34/1) was preponderant, thereby evidencing that the soil organic matter decomposition process and the soil microbial community are influenced by the $\mathrm{C} / \mathrm{N}$ ratio. Furthermore, similar results for the $\beta$-glucosidase enzymatic activity in an area neighboring this work were described by Simon et al. (2017), where the authors describe that the lower $\beta$ glucosidase enzymatic activity was found in the area cultivated with sorghum in succession to the corn crop; however, it can be observed that the amount of zinc for the area published by Simon et al. (2017) and the studied area are very high $\left(15.5 \mathrm{mg} / \mathrm{dm}^{3}\right)$, negatively affecting the enzymatic activity and soil microbial community (Peixoto et al., 2010).

The $\beta$-glucosidase enzyme correlated positively with the soil $\mathrm{MBC}$ and the $\mathrm{C}-\mathrm{CO}_{2}$, possibly indicating that the greater the population and soil basal respiration, the greater the $\beta$ glucosidase enzyme activity in the soil (Table 4). The $\beta$ glucosidase enzyme correlated positively with the soil MBC and $\mathrm{C}-\mathrm{CO}_{2}$, while there was also a positive correlation for the phytomass and the $\mathrm{qCO}_{2}$, indicating that the greater the vegetal fraction on the ground the greater the $\mathrm{qCO}_{2}$, which may also be related to the work of microorganisms in degrading organic compounds (Table 4). A negative correlation was obtained between the soil $\mathrm{qCO}_{2}$ and $\mathrm{MBC}$, showing that the values are in contrast, and the lower the $\mathrm{MBC}$, the higher the metabolic quotient index values (Table 4).

The direct seeding system with soybean under the different cover crops provided a $20 \%$ increase in soybean yield when compared to the fallow area (Figure 6), and the U. Brizantha, $U$. ruzizienses and millet mulches were 4,023.51, 3,850.58 and $3,947.38 \mathrm{~kg} \mathrm{ha}^{-1}$, respectively.

Using the direct seeding system favors the soil microbial community, and implementing cover crops influences the soil microbial ecosystem. Thus, the use of $U$. ruzizienses as a cover plant is recommended in the off-season, as it provided higher soybean yield, a high $\mathrm{C} / \mathrm{N}$ ratio $(35 / 1)$ and a low $\beta$ glucosidase value, allowing protection of the soil for a longer period, in addition to the fact that microbial activity is favored, indicating a higher value of acid phosphatase and MBC.

\section{Materials and Methods}

\section{Location and characterization of the experimental area}

The study was conducted in the experimental area of the Federal University of Mato Grosso do Sul, Chapadão do Sul Campus. The local altitude is $786 \mathrm{~m}$ with Aw tropical humid climate according to the Köppen classification, with an average temperature around $29^{\circ} \mathrm{C}$, annual average rainfall of $1,850 \mathrm{~mm}$ being concentrated in the summer and dryness in winter (Cunha et al., 2013). Rainfall and ambient temperature data were collected during the experimental period (Figure 1). The direct sowing system in the experimental area was implemented in 2013. The system followed the following order, always in the same area: November 2013, soybean sowing; March 2014, sowing of cover crops; November 2014, corn sowing; March 2015, sowing of cover crops; November 2015, soybean sowing; and March 2016, sowing of cover crops. The soil of this area is classified as a dystrophic Red Latosol with a clay texture (Embrapa, 2009), and the granulometric and chemical analyzes are presented in Table 1.

\section{Experimental design and treatment}

The experimental design was in randomized blocks with seven treatments and three replicates, formed by the different cover crops: sorghum (Sorghum bicolor), millet (Pennisetum glaucum (L.) R. Br.), Forage turnip (Raphanus sativus L.), brachiaria (Urochloa brizantha cv. Marandu and Urochloa ruziziensis), crambe (Crambe abyssinica Hochst) and fallow. Soybean crop was planted in all crop cover areas in November 2015, and soil samples were taken for microbiological determinations during the soybean crop.

Each experimental plot established over the cover crop area during the soybean cultivation had dimensions of $7.4 \mathrm{~m} \mathrm{x}$ $10.0 \mathrm{~m}$, with three replications. The cultivating practices adopted for soybean cultivation (planting and cover fertilization, pest, disease and weed control) were carried out according to the recommendations for the region. Soybeans and cover crops are grown for three years, with no-tillage system used.

\section{Sampling and analysis of soil biological attributes}

Soil sampling for determining the microbiological attributes was performed in February 2016 in the soybean R2 stage (full flowering phase) in the 0.0 to $0.10 \mathrm{~m}$ depth layer. Five sub-samples were collected in each plot at three different points, alternating between the two planting lines of the useful area. At each point, five simple samples of equidistant soil were drawn at $0.12 \mathrm{~m}$ with a hole in the center and two holes on each side to the center of the line (Reis Júnior and Mendes, 2007) (Figure 2). In the field, the soil was sieved in a $4.0 \mathrm{~mm}$ mesh sieve and then taken to the laboratory for storage in a cold room at $4^{\circ} \mathrm{C}$ until use. 
The fumigation-extraction methodology was used to evaluate soil microbial biomass carbon (MBC) (Vance et al., 1987), with three replicates in each sample, where three replicates were fumigated with chloroform and three nonfumigated replicates. The fumigated samples were incubated in the dark for $24 \mathrm{~h}$ at room temperature, and the non-fumigated samples were kept at room temperature. After this period, both underwent the extraction process with $0.5 \mathrm{~mol} \mathrm{~L}^{-1} \quad \mathrm{~K}_{2} \mathrm{SO}_{4}$. Determination of the microbial biomass carbon continued by adding concentrated $\mathrm{H}_{2} \mathrm{SO}_{4}$ and $\mathrm{H}_{2} \mathrm{PO}_{4}$ in the fumigated and non-fumigated samples followed by titration with $0.0333 \mathrm{~mol} \mathrm{~L}^{-1}$ ammonium ferrous sulfate.

Soil basal respiration $\left(\mathrm{C}-\mathrm{CO}_{2}\right)$ was determined by quantifying the total carbon dioxide released in the microbial respiration process from $100 \mathrm{~g}$ of soil packed in large-mouthed vials for 11 days of incubation at room temperature $\left(27^{\circ} \mathrm{C} \pm 5\right)$. After incubation, $0.5 \mathrm{~mol} \mathrm{~L}^{-1} \mathrm{NaOH}$ was titrated with $2 \mathrm{~mL}$ of $30 \%$ barium chloride solution and $1 \%$ phenolphthalein added as indicator, and prior precipitation of the carbonate by adding barium chloride and $\mathrm{HCl}$ (Alef and Nannipieri, 1995).

The Anderson and Domsch (1993) was implemented for determining the soil metabolic quotient $\left(\mathrm{qCO}_{2}\right)$, according to the equation: $\mathrm{qCO}_{2}=\mathrm{C}-\mathrm{CO}_{2} / \mathrm{C}-\mathrm{BM}$; where, $\mathrm{C}-\mathrm{CO}_{2}$ is the soil basal respiration rate ( $\mathrm{mg} \mathrm{kg}^{-1}$ of $\mathrm{C}-\mathrm{CO}_{2}$ in the soil), and $\mathrm{MBC}$ is the microbial biomass carbon ( $\mathrm{mg} \mathrm{kg}^{-1}$ of $\mathrm{C}_{\text {mic }}$ in the soil). Enzymatic activities were estimated by evaluating acid phosphatase and $\beta$-glucosidase, both performed according to the methodology described by Tabatabai (1994), using the colorimetric determination of p-nitrophenol after soil incubation with specific substrate of each enzyme, namely $p$ nitrophenol-phosphate and p-nitrophenol- $\beta$-Dglucopyranoside, respectively.

\section{Evaluation of grain yield and soybean production components}

The soybean yield was obtained for the 2015/2016 harvest by collecting and threshing the existing plants in $5.0 \mathrm{~m}$ of the three central lines of each plot, and the productivity values were corrected to $13 \%$ moisture. Determining soybean production components (number of legumes per plant, grains per legume and mass of one thousand grains) was performed by sampling ten plants in each plot.

\section{Vegetative phytomass collection of cover crops}

Shoot samples from each species were collected 60 days after sowing the cover crops (May) to determine the dry mass. The collection was performed with the help of a square of wood with an area of $1.0 \mathrm{~m}^{2}$, randomly thrown into each plot. The total mass of this area was weighed in the field and a sample was taken for drying in a forced ventilation oven at a temperature of $65 \pm 5^{\circ} \mathrm{C}$ until reaching a constant mass. The fresh mass per hectare was determined from the total mass withdrawn per plot, and the dry mass yield of each cover was calculated from the oven dried sample.

\section{Statistical analysis}

Data were submitted to analysis of variance and the means were compared by the Scott Knott test at $5 \%$ probability using the SISVAR software program. Pearson's correlation was also performed between all evaluated parameters using the Genes software program.

\section{Conclusions}

Urochloa ruziziensies and Urochloa brizantha plant cover provided higher biomass carbon content and soil microbial activity, and higher soybean yield. The soil under the sorghum vegetation cover had the lowest microbial efficiency, in spite of higher dry biomass.

\section{Acknowledgements}

"This study was financed in part by the Coordenação de Aperfeiçoamento de Pessoal de Nível Superior - Brazil (CAPES) - Finance Code 001."

\section{References}

Adamczyk B, Kilpeläinen P, Kitunen V, Smolander A (2014) Potential activities of enzymes involved in N, C, P and S cycling in boreal forest soil under different tree species. Pedobiologia. 57:97-102.

Alef K, Nannipieri P (1995) Methods in applied soil microbiology and brochemistry. Academic Press, London.

Anderson JPE, Domsch KH (1993) The metabolic quotient $\left(q \mathrm{CO}_{2}\right)$ as a specific activity parameter to assess the effects of environment conditions, such as $\mathrm{pH}$, on the microbial biomass of forest soils. Soil Biol Biochem. 25:393-395.

Balota EL, Colozzi-Filho A, Andrade DS, Dick RP (2003) Microbial biomass in soils under different tillage and crop rotation systems. Biol Fertil Soils. 38:15-20.

Bhavya, VP, Anil Kumar S, Kiran SK, Ashok Alur S, Shivakumar KM, Shivanna M (2018) Effect of different cropping system on important soil enzyme activity, organic carbon and microbial activity with different depth. Int J Curr Microbiol App Sci. 7: 315- 322.

Błońska E, Lasota J, Zwydak M (2017) The relationship between soil properties, enzyme activity and land use. Leśne Prace Badawcze. 78:39-44.

Cardoso EJBN, Andreote FD (2016) Microbiologia do solo. Fealq, Piracicaba.

Chávez LF, Escobar LF, Anghinoni I, Carvalho PCDF, Meurer EJ (2011) Diversidade metabólica e atividade microbiana no solo em sistema de integração lavoura-pecuária sob intensidades de pastejo. Pesqui Agropecu Bras. 46:12541261.

Cunha FF, Magalhães FF, Castro MA (2013) Métodos para estimativa da evapotranspiração de referência para Chapadão do Sul - MS. Engenharia na agricultura. 21:159172.

Embrapa (2009) Sistema brasileiro de classificação de solos. Embrapa, Rio de Janeiro.

Faust K, Raes J (2012) Microbial interactions: from networks to models. Nat Rev Microbiol. 10:538-550.

Ferreira, ME, Caramori SS, Zago LMS, Moreira AKO, SilvaNeto CM, Nabout JC (2018) Biochemical activity in Brazilian Cerrado soils is differentially affected by perennial and annual crops. Aust J Crop Sci. 12:235-242. 
Gessner MO, Swan CM, Dang CK, Mckie BG, Bardgett RD, Wall DH, Ha" Ttenschwiler S (2010) Diversity meets decomposition. Trends Ecol Evol (Amst.). 25:372-380.

Gomide PHO, Silva MLN, Soares CRFS (2011) Atributos físicos, químicos e biológicos do solo em ambientes de voçorocas no município de Lavras - MG. Rev Bras Cienc Solo. 35:567-577.

Guimarães NF, Gallo AS, Fontanetti A, Meneghin SP, De Souza MDB, Morinigo KPG, Da Silva RF (2017) Biomassa e atividade microbiana do solo em diferentes sistemas de cultivo do cafeeiro. Revista de Ciências Agrárias. 40:34-44.

Haichar FEZ, Santaella C, Heulin T, Achouak W (2014) Root exudates mediated interactions belowground. Soil Biol Biochem. 77:69-80.

Kunze ACMD, Epping J, Loffaguen JC, Schuh R, Lovato PE (2011) Phosphatase activity in sandy soil influenced by mycorrhizal and non-mycorrhizal cover crops. Rev Bras Cienc Solo. 35:705-711.

Koper J, Piotrowska A (1999) Aktywność enzymatyczna gleby jako parametr jej żyzności wywołany systemem uprawy. Zeszyty Problemowe Postępów Nauk Rolniczych Probl. 467: 127-134.

Lisboa BB, Vargas LK, Silveira AO, Martins AF, Selbach PA (2012) Indicadores microbianos de qualidade do solo em diferentes sistemas de manejo. Rev Bras Cienc Solo. 36:4555.

Lourente ERP, Mercante FM, Alovisi AMT, Gomes, CF, Gasparini AS, Nunes CM (2011) Atributos microbiológicos, químicos e físicos de solo sob diferentes sistemas de manejo e condições de cerrado. Pesqui Agropecu Trop. 41:20-28.

Makoi JHJR, Ndakidemi PA (2008) Selected soil enzymes: examples of their potential roles in the ecosystem. Afr J Biotechnol. 7:181-191.

Massenssini AM, Totola M, Borges AC, Costa MD (2015) Potential phosphate solubilization mediated by rhizospheric microbiota of eucalyptus cultivated in a typical toposequence of the zona da mata, Minas Gerais, Brazil. Rev Bras Cienc Solo. 39:692-700.

Medeiros EV, Duda GP, dos Santos LAR, de Sousa Lima JR, de Almeida-Cortéz JS, Hammecker C, Lardy L, Cournac L (2017) Soil organic carbon, microbial biomass and enzyme activities responses to natural regeneration in a tropical dry region in Northeast Brazil. Catena. 151: 137-146.

Mendes IC, Fernandes MF, Chaer GM, Reis Junior FB (2012) Biological functioning of brazilian cerrado soils under different vegetation types. Plant Soil. 359:183-195.
Peixoto RS, Chaer GM, Reis Júniro FB, Mendes IC (2010) A decade of land use contributes to changes in the chemistry, biochemistry and bacterial community structures of soils in the cerrado. Antonie Van Leeuwenhoek. 98:403-413.

Raij BV, Silva NMD, Bataglia OC, Cantarella H, Quaggio JÁ, Furlani AMC (1996) Recomendações de adubação e calagem para o estado de São Paulo. Embrapa, Campinas.

Raynaud X, Nunan N (2014) Spatial ecology of bacteria at the microscale in soil. PLoS One. 9:1-8.

Reis Junior FB, Mendes IC (2007) Biomassa microbiana do solo. Embrapa, Planaltina.

Roscoe R, Mercante FM, Mendes IDC, Reis Júnior FB, Santos JCFE, Hungria M (2006) Biomassa microbiana do solo: fração mais ativa da matéria orgânica. In: Roscoe $R$, Mercante FM, Salton JC (ed) Dinâmica da matéria orgânica do solo em sistemas conservacionistas: modelagem matemática e métodos auxiliares. Embrapa, Dourados.

Simon CA, Cordeiro MS, De Lima SF, Brasil MDS, De David CH, Secco VA (2017) Microbial activity in a soil with cover crops in succession with maize in a no-tillage system. Brazilian Journal of Agriculture. 92:198-207.

Sousa DMGD, Lobato E (2004) Adubação com fósforo. Cerrado: correção do solo e adubação. Embrapa, Brasília.

Stott DE, Andrews SS, Liebig MA, Wienhold BJ, Karlen DL (2010) Evaluation of $\beta$-glucosidase activity as a soil quality indicator for the soil management assessment framework. Soil Biol Biochem. 74:107-119.

Tabatabai MA (1994) Soil enzymes. In: Page AL, Miller EM, Keeney DR (ed) Methods of soil analysis, part 2, chemical and microbiological properties. American Society of Agronomy. 1:903-947.

Taiz L, Zeiger E, Møller IM, Murphy S (2017) Fisiologia e desenvolvimento vegetal. 6ed, Artmed Editora, Porto Alegre.

Torres JLR, Pereira MG, Fabian AJ (2008) Produção de fitomassa por plantas de cobertura e mineralização de seus resíduos em plantio direto. Pesqui Agropecu Bras., 43:421-428.

Vance ED, Bookes PC, Jenkinson DS (1987) An extraction method for measuring soil microbial biomass $C$. Soil Biol Biochem. 9:703-707

Zhang Q, Zhou W, Liang G, Sun J, Wang X, He P (2015) Distribution of soil nutrients, extracellular enzyme activities and microbial communities across particle-size fractions in a long-term fertilizer experiment. Appl Soil Ecol. 94: 59-71. 